\title{
THE EFFECT OF HATHA YOGA THERAPY ON THE BLOOD PRESSURE OF PRIMARY HYPERTENSION PATIENTS OF PRODUCTIVE AGE
}

\author{
Darwin Tamba*, Ridha Dharmajaya, Nur Asnah Sitohang \\ Department of Medical Surgical Nursing, Faculty of Nursing, Universitas Sumatera Utara, Indonesia
}

\section{Article Information}

Received: 30 September 2020

Revised: 30 December 2020

Accepted: 1 March 2021

\section{*Corresponding Author}

Darwin Tamba

darwintamba08@gmail.com

\section{DOI}

10.20884/1.jks.2021.16.1.1543

\begin{abstract}
Untreated hypertension can lead to serious complications. One of the nonpharmacological therapies for treating hypertension is hatha yoga. The study aimed to determine the effect of hatha yoga therapy on the blood pressure of those of productive age among primary hypertension patients. The research type was a quasi-experiment with pre-posttest with control group design. The number of study samples was 64 respondents consisting of 32 respondents in the intervention group (who were given 35 minutes of hatha yoga therapy and Amlodipine $5 \mathrm{mg} /$ day for 4 weeks) and 32 respondents in the control group who received Amlodipine $5 \mathrm{mg} /$ day for 4 weeks. The data analysis used the dependent test (paired t test). The results showed that the mean of systolic and diastolic of blood pressure before the therapy in primary hypertension patients in the intervention group was $161.84 / 93.25 \mathrm{mmHg}$, while in the control group it was $161.66 / 93.37 \mathrm{mmHg}$. The mean of the systolic and diastolic blood pressure after therapy in the primary hypertensive patients in the intervention group was 122.87 / $71.69 \mathrm{mmHg}$, and in the control group it was $127.66 / 73.13 \mathrm{mmHg}$. The statistical tests using paired t-test showed that the $p$ value was $<\alpha=0.05$. In conclusion, hatha yoga therapy has the effect of lowering blood pressure for those of productive age among primary hypertension patients.
\end{abstract}

Keywords: Blood pressure; hatha toga therapy; primary hypertension

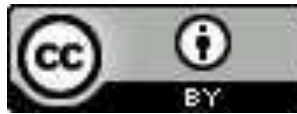

ISSN : 1907-6637

e-ISSN : 2579-9320

\section{INTRODUCTION}

Hypertension is the increase of blood pressure above the normal level with a systolic and diastolic number of more than 140/90 $\mathrm{mmHg}$. Increased and prolonged high blood pressure can damage blood vessels in organs such as the kidneys, heart, brain and eyes, causing complications such as stroke, coronary heart disease, kidney failure, and blindness. Hypertension is also known as the silent killer (Ministry of Health of the Republic of Indonesia, 2016).

Based on the causes of hypertension, it is divided into two, namely primary hypertension (around $90 \%$ of total cases of hypertension) and secondary hypertension (around 10\% of the total number of hypertension cases). Primary hypertension is a type of hypertension where the cause is unknown or idiopathic (Ministry of Health of the Republic of Indonesia, 2014).

The World Health Organization (2013) noted that, in the world, there were 17,000 people per year who died from cardiovascular diseases and 9,400 of them were caused by complications resulting from hypertension. The prevalence of world hypertension reached to $29.2 \%$ in men and $24.8 \%$ in women (WHO, 2013). In America, there were 74.5 million people who experienced hypertension (American Heart Association, 2013). While in Indonesia, it was estimated that $25.8 \%$ of people experienced hypertension (Ministry of Health of the Republic of Indonesia, 2013). Particularly in North Sumatra, Indonesia, it was recorded that 151,939 people suffered from hypertension (Health Office, 2015).

One of the non-pharmacological primary hypertension treatments is hatha yoga, which is a program of unification of the body, mind and spirit. Hatha yoga is a combination of breathing techniques (pranayama), relaxation and stretching or posture exercises (asanas) (Sindhu, 2015). Asana aims to stimulate the release of endorphin hormones, which function as a natural sedative produced by the brain to create a sense of comfort. Increased endorphin hormones 
have the effect of reducing high blood pressure. Pranayama in yoga is a systematic and voluntary controlled breathing exercise, which results in an increase in the activity of the parasympathetic nervous system to stimulate the release of dopamine levels, reduce emotional stress and relax blood vessels so that blood pressure can decrease. It is therefore that hatha yoga is recommended as a complementary therapy for hypertensive sufferers (Sindhu, 2015).

\section{METHOD}

Study design

The research design used a quasi-experimental, preposttest with control group design (Polit \& Beck, 2012).

\section{Instrument}

The instrument used in this study was a tensimeter to measure the respondent's blood pressure before and after being given treatment in both the control group and the intervention group.

\section{Intervention}

The intervention group received the hatha yoga therapy including pranayama and asana for 30 minutes per session and this was followed by relaxation for 5 minutes -35 minutes for the total duration of the intervention. The intervention group received the hatha yoga that was carried out for a month, twice a week, and they were also prescribed pharmacological treatment from doctors i.e. amlodipine $1 \times 5 \mathrm{mg} /$ day for 4 weeks. Meanwhile, the control group only received the same pharmacological treatment The examination and measurement of blood pressure (systolic and diastolic) was measured twice: the first time was before treatment and the last was after receiving hatha yoga and amlodipine therapy for the intervention group and after only receiving amlodipine for the control group.

\section{Data Analysis}

\section{RESULT}

This research was conducted in Mitra Medika Hospital, Medan from April to May 2019. The total sample was 64 respondents according to the inclusion and exclusion criteria.

\section{Respondent Characteristics}

Variables involved in univariate analysis included age, gender, education, smoking history, and the duration of drug consumption as can be seen in Table 1.

Table 1. Respondent characteristics $(n=64)$

\begin{tabular}{lcccc}
\hline \multirow{2}{*}{ Variable } & \multicolumn{2}{c}{ Intervention Group } & \multicolumn{2}{c}{ Control Group } \\
\cline { 2 - 5 } & Frequency (f) & Percentage (\%) & Frequency (f) & Percentage (\%) \\
\hline Age & 7 & & & 9.4 \\
25-35 years old & 15 & 21.9 & 18 & 56.2 \\
36-45 years old & 10 & 46.9 & 11 & 34.4 \\
46-55 years old & 15 & 31.2 & 14 & 43.75 \\
Gender & 17 & 46.9 & 18 & 56.25 \\
$\quad$ Male & 9 & 53.1 & 11 & 34.4 \\
$\quad$ Female & 23 & 28.1 & 21 & 65.6 \\
Education & & 71.9 & 13 & 40.6 \\
$\quad$ Junior high school & 13 & & 19 & 59.4 \\
$\quad$ Senior high school & 19 & 40.6 & & \\
Smoking history & & 59.4 & & \\
$\quad$ Yes, smoked & & & & \\
$\quad$ Not smoked & & & & \\
Duration of taking drugs & & & & \\
\hline \hline
\end{tabular}




\begin{tabular}{lcccc}
\hline \hline \multirow{2}{*}{ Variable } & \multicolumn{2}{c}{ Intervention Group } & \multicolumn{2}{c}{ Control Group } \\
\cline { 2 - 5 } & Frequency (f) & Percentage (\%) & Frequency (f) & Percentage (\%) \\
\hline$<7$ days & 17 & 53.1 & 16 & 50.0 \\
$7-21$ days & 10 & 31.3 & 11 & 34.4 \\
$>21-30$ days & 5 & 15.6 & 5 & 15.6 \\
\hline
\end{tabular}

Table 1 explained that the majority of respondents in the intervention group were aged 36-45 years old, which was as many as 15 people $(46.9 \%)$, while the majority of respondents in the control group were $36-45$ years old (18 people or $56.3 \%)$. Most respondents were women, which was as many as 17 people (53.1\%) and 18 people (56.3\%) in the intervention and control group respectively. Generally, the respondents were high school graduates: 23 people $(71.9 \%)$ in the intervention group and 21 people $(65.6 \%)$ in the control group. The majority of the smoking history in the intervention group was 13 people who smoked (40.6\%) and 19 people $(59.4 \%)$ who had not smoked. As many as 17 people $(53.1 \%)$ had taken medication $<7$ days in the intervention group whilst in the control group it was 16 people $(50.0 \%)$.

Systolic and Diastolic Blood Pressure of Primary Hypertensive Patients in the Intervention Group

The systolic blood pressure of primary hypertensive patients in the intervention group can be seen in Table 2.

Table 2. Systolic and diastolic blood pressure of primary hypertensive patients in the intervention group ( $n=64)$

\begin{tabular}{|c|c|c|c|c|c|}
\hline Week & & Variable & Average & Maximum & Minimum \\
\hline \multirow{8}{*}{ Week 1} & \multirow{2}{*}{ Pretreatment 1} & Systolic & 161.84 & 179 & 151 \\
\hline & & Diastolic & 93.25 & 100 & 90 \\
\hline & \multirow{2}{*}{ Post treatment 1} & Systolic & 158.81 & 165 & 150 \\
\hline & & Diastolic & 92.50 & 99 & 89 \\
\hline & \multirow{2}{*}{ Pretreatment 2} & Systolic & 154.94 & 160 & 145 \\
\hline & & Diastolic & 90.81 & 97 & 88 \\
\hline & \multirow{2}{*}{ Post treatment 2} & Systolic & 152.09 & 160 & 140 \\
\hline & & Diastolic & 86.16 & 93 & 80 \\
\hline \multirow{8}{*}{ Week 2} & \multirow{2}{*}{ Pretreatment 3} & Systolic & 147.97 & 160 & 139 \\
\hline & & Diastolic & 83.88 & 92 & 76 \\
\hline & \multirow{2}{*}{ Post treatment 3} & Systolic & 147.19 & 160 & 139 \\
\hline & & Diastolic & 82.59 & 90 & 76 \\
\hline & \multirow{2}{*}{ Pretreatment 4} & Systolic & 143.28 & 158 & 133 \\
\hline & & Diastolic & 80.97 & 90 & 72 \\
\hline & \multirow{2}{*}{ Post treatment 4} & Systolic & 141.53 & 157 & 133 \\
\hline & & Diastolic & 79.84 & 87 & 72 \\
\hline \multirow{8}{*}{ Week 3} & \multirow{2}{*}{ Pretreatment 5} & Systolic & 139.03 & 158 & 130 \\
\hline & & Diastolic & 78.53 & 86 & 71 \\
\hline & \multirow{2}{*}{ Post treatment 5} & Systolic & 137.53 & 158 & 130 \\
\hline & & Diastolic & 77.00 & 85 & 70 \\
\hline & \multirow{2}{*}{ Pretreatment 6} & Systolic & 136.03 & 155 & 125 \\
\hline & & Diastolic & 76.66 & 85 & 70 \\
\hline & \multirow{2}{*}{ Post treatment 6} & Systolic & 134.31 & 150 & 122 \\
\hline & & Diastolic & 75.66 & 82 & 70 \\
\hline \multirow{8}{*}{ Week 4} & \multirow{2}{*}{ Pretreatment 7} & Systolic & 132.16 & 149 & 122 \\
\hline & & Diastolic & 74.72 & 80 & 70 \\
\hline & \multirow{2}{*}{ Post treatment 7} & Systolic & 131.44 & 145 & 122 \\
\hline & & Diastolic & 73.09 & 80 & 70 \\
\hline & \multirow{2}{*}{ Pretreatment 8} & Systolic & 126.59 & 140 & 110 \\
\hline & & Diastolic & 72.69 & 78 & 70 \\
\hline & \multirow{2}{*}{ Post treatment 8} & Systolic & 122.87 & 136 & 110 \\
\hline & & Diastolic & 71.69 & 76 & 69 \\
\hline
\end{tabular}

Table 2 reports that the systolic blood pressure among primary hypertensive patients after hatha yoga decreased from $151 \mathrm{mmHg}$ after the first treatment to $110 \mathrm{mmHg}$ after the eighth treatment. The maximum the systolic blood pressure, after the hatha yoga, decreased by was from 179 $\mathrm{mmHg}$ for the first treatment to $136 \mathrm{mmHg}$ after the eighth treatment and the mean blood pressure for each treatment decreased from $161.84 \mathrm{mmHg}$ in the first treatment to $122.87 \mathrm{mmHg}$ after the eighth treatment. The minimum diastolic blood pressure, after the hatha yoga, decreased by was from $90 \mathrm{mmHg}$ in the first treatment to $69 \mathrm{mmHg}$ after the eighth treatment. The maximum the diastolic blood pressure, after the hatha yoga, decreased by was from 100 $\mathrm{mmHg}$ for the first treatment to $76 \mathrm{mmHg}$ after the eighth treatment and the mean blood pressure for each treatment decreased from $93.25 \mathrm{mmHg}$ for the first treatment to 71.69 $\mathrm{mmHg}$.

Systolic and Diastolic Blood Pressure of Primary Hypertensive Patients in the Control Group. 
The systolic and diastolic blood pressures of primary hypertensive patients in the control group can be seen in Table 3 .

Table 3. Systolic and diastolic blood pressure of primary hypertensive patients in the control group $(n=64)$

\begin{tabular}{|c|c|c|c|c|c|}
\hline Week & & Variable & Average & Maximum & Minimum \\
\hline \multirow{8}{*}{ Week 1} & \multirow{2}{*}{ Pretreatment 1} & Systolic & 161.66 & 170 & 154 \\
\hline & & Diastolic & 93.37 & 100 & 90 \\
\hline & \multirow{2}{*}{ Post treatment 1} & Systolic & 158.97 & 170 & 140 \\
\hline & & Diastolic & 93.28 & 99 & 89 \\
\hline & \multirow{2}{*}{ Pretreatment 2} & Systolic & 156.09 & 165 & 150 \\
\hline & & Diastolic & 87.06 & 100 & 80 \\
\hline & \multirow{2}{*}{ Post treatment 2} & Systolic & 154.62 & 161 & 140 \\
\hline & & Diastolic & 86.56 & 93 & 70 \\
\hline \multirow{8}{*}{ Week 2} & \multirow{2}{*}{ Pretreatment 3} & Systolic & 152.06 & 160 & 140 \\
\hline & & Diastolic & 83.59 & 93 & 76 \\
\hline & \multirow{2}{*}{ Post treatment 3} & Systolic & 148.31 & 158 & 140 \\
\hline & & Diastolic & 83.28 & 90 & 76 \\
\hline & \multirow{2}{*}{ Pretreatment 4} & Systolic & 147.13 & 160 & 137 \\
\hline & & Diastolic & 80.91 & 90 & 72 \\
\hline & \multirow{2}{*}{ Post treatment 4} & Systolic & 146.53 & 158 & 137 \\
\hline & & Diastolic & 80.78 & 87 & 70 \\
\hline \multirow{8}{*}{ Week 3} & \multirow{2}{*}{ Pretreatment 5} & Systolic & 143.81 & 159 & 130 \\
\hline & & Diastolic & 78.97 & 90 & 70 \\
\hline & \multirow{2}{*}{ Post treatment 5} & Systolic & 141.31 & 157 & 130 \\
\hline & & Diastolic & 78.88 & 90 & 70 \\
\hline & \multirow{2}{*}{ Pretreatment 6} & Systolic & 138.53 & 155 & 125 \\
\hline & & Diastolic & 77.78 & 87 & 70 \\
\hline & \multirow{2}{*}{ Post treatment 6} & Systolic & 135.31 & 150 & 123 \\
\hline & & Diastolic & 77.41 & 86 & 70 \\
\hline \multirow{8}{*}{ Week 4} & \multirow{2}{*}{ Pretreatment 7} & Systolic & 133.91 & 164 & 118 \\
\hline & & Diastolic & 75.13 & 80 & 70 \\
\hline & \multirow{2}{*}{ Post treatment 7} & Systolic & 132.47 & 145 & 120 \\
\hline & & Diastolic & 74.84 & 82 & 70 \\
\hline & \multirow{2}{*}{ Pretreatment 8} & Systolic & 129.91 & 149 & 116 \\
\hline & & Diastolic & 73.19 & 80 & 70 \\
\hline & \multirow{2}{*}{ Post treatment 8} & Systolic & 127.66 & 142 & 112 \\
\hline & & Diastolic & 73.13 & 80 & 70 \\
\hline
\end{tabular}

Table 3 shows the systolic blood pressure in patients with primary hypertension. In the control group, it decreased from $154 \mathrm{mmHg}$ at the first treatment to $112 \mathrm{mmHg}$ after the eighth treatment. The maximum systolic blood pressure, after receiving the treatment, decreased by was from 170 $\mathrm{mmHg}$ to $142 \mathrm{mmHg}$ after the treatment and the mean blood pressure for each treatment decreased from 161.66 $\mathrm{mmHg}$ to $127.66 \mathrm{mmHg}$.

The minimum diastolic blood pressure after treatment decreased from $90 \mathrm{mmHg}$ to $70 \mathrm{mmHg}$; the maximum systolic blood pressure decreased from $100 \mathrm{mmHg}$ to 80 $\mathrm{mmHg}$ after treatment and the mean blood pressure after treatment decreased from $93.37 \mathrm{mmHg}$ to $73.13 \mathrm{mmHg}$.

\section{Bivariate Analysis}

Bivariate analysis was used to examine differences in blood pressure before and after intervention among primary hypertensive patients.

The Effect of Hatha Yoga Therapy on Systolic and Diastolic Blood Pressure for Each Treatment in Primary Hypertension Patients

Table 4. The effect of hatha yoga therapy on systolic and diastolic blood pressure for each treatment in primary hypertensive patients in the intervention group

\begin{tabular}{|c|c|c|c|c|}
\hline & \multicolumn{4}{|c|}{ Variable } \\
\hline & \multicolumn{2}{|c|}{ Systolic } & \multicolumn{2}{|c|}{ Diastolic } \\
\hline & Pre-test & Post-test & Pre-test & Post-test \\
\hline \multicolumn{5}{|l|}{ Treatment 1} \\
\hline Mean \pm SD & $161.75 \pm 4.277$ & $158.89 \pm 4.704$ & $93.31 \pm 3,270$ & $92.89 \pm 3.056$ \\
\hline Mean difference \pm SB & \multicolumn{2}{|c|}{$2.86 \pm 0.427$} & \multicolumn{2}{|c|}{$0.42 \pm 0.214$} \\
\hline $95 \% \mathrm{Cl}$ & \multicolumn{2}{|c|}{$1,609-4,571$} & \multicolumn{2}{|c|}{$0.069-0.775$} \\
\hline$p$ & \multicolumn{2}{|c|}{0.000} & \multicolumn{2}{|c|}{0.020} \\
\hline $\mathrm{t}$ & .171 & -.132 & -.152 & -.745 \\
\hline
\end{tabular}


Tamba, D., Dharmajaya, R., \& Sitohang, N. A. (2021)

\begin{tabular}{|c|c|c|c|c|}
\hline & \multicolumn{4}{|c|}{ Variable } \\
\hline & \multicolumn{2}{|c|}{ Systolic } & \multicolumn{2}{|c|}{ Diastolic } \\
\hline & Pre-test & Post-test & Pre-test & Post-test \\
\hline \multicolumn{5}{|l|}{ Treatment 2} \\
\hline Mean \pm SD & $155.52 \pm 4.163$ & $153.36 \pm 5.015$ & $88.94 \pm 4,000$ & $86.36 \pm 4,064$ \\
\hline Mean difference \pm SB & \multicolumn{2}{|c|}{$2.16 \pm 0.852$} & \multicolumn{2}{|c|}{$2.58 \pm 0.064$} \\
\hline $95 \% \mathrm{Cl}$ & \multicolumn{2}{|c|}{$1,012-3,301$} & \multicolumn{2}{|c|}{$1,503-3,653$} \\
\hline$p$ & \multicolumn{2}{|c|}{0.000} & \multicolumn{2}{|c|}{0.000} \\
\hline $\mathrm{t}$ & -1.113 & -2.071 & 4.222 & -.397 \\
\hline \multicolumn{5}{|l|}{ Treatment 3} \\
\hline Mean \pm SD & $150.02 \pm 7,117$ & $147.75 \pm 5.809$ & $83.73 \pm 4.141$ & $82.94 \pm 3,800$ \\
\hline Mean difference \pm SB & \multicolumn{2}{|c|}{$2.27 \pm 1.308$} & \multicolumn{2}{|c|}{$0.79 \pm 0.341$} \\
\hline $95 \% \mathrm{Cl}$ & \multicolumn{2}{|c|}{$0.994-3,537$} & \multicolumn{2}{|c|}{$0.253-1.340$} \\
\hline$p$ & \multicolumn{2}{|c|}{0.001} & \multicolumn{2}{|c|}{0.005} \\
\hline $\mathrm{t}$ & -2.385 & -.772 & .270 & -.721 \\
\hline \multicolumn{5}{|l|}{ Treatment 4} \\
\hline Mean \pm SD & $145.20 \pm 7,069$ & $144.03 \pm 6,794$ & $80.94 \pm 3,813$ & $80.31 \pm 3,536$ \\
\hline Mean difference \pm SB & \multicolumn{2}{|c|}{$1.17 \pm 0.275$} & \multicolumn{2}{|c|}{$0.43 \pm 0.277$} \\
\hline $95 \% \mathrm{Cl}$ & \multicolumn{2}{|c|}{$0.033-2.311$} & \multicolumn{2}{|c|}{$0.134-1.116$} \\
\hline$p$ & \multicolumn{2}{|c|}{0.044} & \multicolumn{2}{|c|}{0.013} \\
\hline $\mathrm{t}$ & -2.243 & -3.145 & .065 & -1.062 \\
\hline Treatment 5 & & & & \\
\hline Mean \pm SD & $141.42 \pm 8,271$ & $139.42 \pm 7,184$ & $78.75 \pm 4.239$ & $77.94 \pm 4.397$ \\
\hline Mean difference \pm SB & 2.00 & & & 58 \\
\hline $95 \% \mathrm{Cl}$ & 0.70 & 91 & 0.3 & 275 \\
\hline$p$ & & & & \\
\hline $\mathrm{t}$ & -2.398 & -2.166 & -.410 & -1.733 \\
\hline Treatment 6 & & & & \\
\hline Mean \pm SD & $137.28 \pm 7,531$ & $134.81 \pm 6,671$ & $77.22 \pm 3,811$ & $76.53 \pm 4,024$ \\
\hline Mean difference \pm SB & 2.4 & & & \\
\hline $95 \% \mathrm{Cl}$ & 1,11 & 33 & 0.0 & 350 \\
\hline$p$ & & & & \\
\hline $\mathrm{t}$ & -1.336 & -.597 & -1.185 & -1.769 \\
\hline Treatment 7 & & & & \\
\hline Mean \pm SD & $133.03 \pm 8.365$ & $131.95 \pm 6,627$ & $74.92 \pm 3,031$ & $73.97 \pm 3.065$ \\
\hline Mean difference \pm SB & 1.08 & & & \\
\hline $95 \% \mathrm{Cl}$ & 0.00 & 53 & & 492 \\
\hline$p$ & & & & \\
\hline $\mathrm{t}$ & -.835 & -.619 & -.533 & -2.365 \\
\hline Treatment 8 & & & & \\
\hline Mean \pm SD & $128.25 \pm 7.950$ & $125.27 \pm 7,394$ & $72.94 \pm 2,630$ & $72.41 \pm 2.505$ \\
\hline Mean difference \pm SB & 2.98 & & & 25 \\
\hline $95 \% \mathrm{Cl}$ & 2,13 & 39 & & 355 \\
\hline$p$ & & & & \\
\hline $\mathrm{t}$ & -1.691 & -2.714 & -.758 & -2.378 \\
\hline
\end{tabular}

Based on the Table 4, the results of the t test statistical test on systolic blood pressure obtained the $p$-value $<\alpha=0.05$ for each treatment, meaning that Null Hypothesis $(\mathrm{HO})$ is rejected. There were differences in systolic blood pressure before and after the treatment of hatha yoga therapy. The results of the t test statistical test on diastolic blood pressure obtained the $p$-value $<\alpha=0.05$ of each treatment, meaning that $\mathrm{HO}$ was rejected. It means that there was an effect of hatha yoga therapy on reducing blood pressure in primary hypertensive patients.

The Effect of Hatha Yoga Therapy on Decreasing Systolic and Diastolic Blood Pressure in Primary Hypertensive Patients 
The effect of hatha yoga therapy on reducing systolic and diastolic blood pressure in primary hypertensive patients can be seen in Table 5 .

Table 5. The effect of hatha yoga therapy on systolic and diastolic blood pressure among primary hypertensive patients in the control group

\begin{tabular}{|c|c|c|c|c|}
\hline & \multicolumn{4}{|c|}{ Variable } \\
\hline & \multicolumn{2}{|c|}{ Systolic } & \multicolumn{2}{|c|}{ Diastolic } \\
\hline & Pre-test & Post-test & Pre-test & Post-test \\
\hline Mean \pm SD & $161.75 \pm 4.353$ & $125.27 \pm 7,394$ & $93.31 \pm 3,270$ & $72.41 \pm 2.505$ \\
\hline Mean difference \pm SB & \multicolumn{2}{|c|}{$36.48 \pm 3.041$} & \multicolumn{2}{|c|}{$20.9 \pm 0.765$} \\
\hline $95 \% \mathrm{Cl}$ & \multicolumn{2}{|c|}{$34,659-38,310$} & \multicolumn{2}{|c|}{$19,821-21,492$} \\
\hline $\mathrm{p}$ & \multicolumn{2}{|c|}{0.000} & \multicolumn{2}{|c|}{0.020} \\
\hline
\end{tabular}

Table 5 shows the results of the $t$ test statistical test obtained the $\mathrm{p}$-value $<\alpha=0.05$ that means that $\mathrm{HO}$ is accepted or in other words, there are differences in the systolic and diastolic blood pressure of primary hypertensive patients before and after practicing hatha yoga therapy in the intervention and control groups.

\section{DISCUSSION}

Blood Pressure of Hypertensive Patients in the Intervention Group

Statistical tests showed that the systolic and diastolic blood pressure in primary hypertensive respondents was significantly reduced by $38.97 \mathrm{mmHg}$. It could be because the respondent received therapeutic treatment from a doctor as well as non-pharmacological therapy using hatha yoga regularly over 4 weeks with 8 meetings. According to Palmer \& Williams (2009), the treatment for primary hypertension can be done pharmacologically and nonpharmacologically. Non-pharmacological medications can be used as a complement to get a medicinal effect when anti-hypertensive drugs are given.

\section{Blood Pressure of Hypertensive Patients in the Control Group}

In this study, primary hypertension patients who received pharmacological treatment experienced a significant reduction in systolic and diastolic blood pressure, but interestingly it sometimes increased or decreased. This may be because the patients regularly follow the medication given by the doctor. This is in accordance with JNC (2013) who stated that the goal of hypertensive treatment is not only to reduce blood pressure but also to reduce and prevent complications due to hypertension so that sufferers can increase their strength.

According to Gunawan (2015), preventive efforts, besides drugs prescribed by doctors, are also beneficial for people with hypertension to prevent the disease from getting any worse. Hypertensive patients need to check their blood pressure regularly in order to know the development and state of their blood pressure so that they can maintain a healthy lifestyle to keep their blood pressure in a normal range.

Differences in Blood Pressure of Hypertensive Patients between the Intervention Group and the Control Group

Table 2 shows that the decrease in systolic blood pressure before and after the implementation of yoga hatha therapy in the intervention group of primary hypertensive patients was $38.97 \mathrm{mmHg}$ (before $161.84 \mathrm{mmHg}$ and after 122.87 $\mathrm{mmHg}$ ) and a decrease in diastolic blood pressure by 21.56 $\mathrm{mmHg}$ (before $93.25 \mathrm{mmHg}$ and after $71.69 \mathrm{mmHg}$ ). Meanwhile, Table 3 shows that the decrease in systolic and diastolic blood pressure in the control group was 34.0 $\mathrm{mmHg}$ (before $161.66 \mathrm{mmHg}$ and after $127.66 \mathrm{mmHg}$ ) and the decrease in diastolic blood pressure was $20.24 \mathrm{mmHg}$ (before $93.37 \mathrm{mmHg}$ and after $73.13 \mathrm{mmHg}$ ) so that the mean difference in the decrease of systolic blood pressure was $4.97 \mathrm{mmHg}$ (from $38.97 \mathrm{mmHg}$ to $34.0 \mathrm{mmHg}$ ) and the mean difference in diastolic blood pressure reduction was $1.32 \mathrm{mmHg}$ (from $21.56 \mathrm{mmHg}$ to $20.24 \mathrm{mmHg}$ ). According to Cohen et al. (2011) in Ridwan (2009), yoga therapy is very helpful for those suffering from hypertension.

The Effect of Hatha Yoga Therapy on the Blood Pressure of Primary Hypertensive Patients

The basic mechanism of increasing systolic and diastolic blood pressure corresponds to a decrease in the elasticity of the blood vessels and the ability to stretch the large arteries. Changes in sympathetic nervous system activity with increased norepinephrine cause a decrease in the sensitivity of the beta-adrenergic receptor system, resulting in decreased muscle relaxation function of blood vessels (Palmer \& Williams, 2009).

Vasoconstriction causes decreased blood flow to the kidneys, resulting in the release of renin. Renin stimulates the formation of angiotensin I which is then converted by the ACE (Angiotensin Converting Enzyme) to angiotensin II, a potent vasoconstrictor, which in turn stimulates aldosterone secretion by the adrenal cortex. This hormone causes retention of sodium and water by the renal tubules, causing an increase in intravascular volume. All of these factors tend to trigger hypertension (Palmer \& Williams, 2009).

Asana in yoga can stimulate the release of endorphin hormones which function as natural sedatives produced by the brain that creates a sense of comfort. Increasing levels of endorphins in the body can reduce high blood pressure. Pranayama in yoga is a form of voluntary controlled breathing that affects the increase in activity of the parasympathetic nervous system and increases the level of dopamine, which function is to reduce emotional stress as well as relaxing blood vessels. It is therefore that yoga is recommended as a complementary therapy for hypertension sufferers (Sindhu, 2015).

Hatha yoga therapy affects systolic and diastolic blood pressure in patients with primary hypertension. This is in line with Cramer et al. (2014) who reported that the provision of yoga that is done regularly for 8 weeks can significantly influence changes in blood pressure in hypertensive patients.

\section{CONCLUSION AND RECOMMENDATION}


There is an effect of hatha yoga and amlodipine therapy in reducing blood pressure. It is recommended that hypertensive patients practice hatha yoga therapy as a nonpharmacological therapy in managing hypertension.

\section{REFERENCES}

Ajjimaporn, PT., A, Rachiwong, S., Siripornpanich, V., (2018). Effects of 8 Weeks of Modified Hatha Yoga Training on Resting-State Brain Activity and The P300 ERP in Patients With Physical DisabilityRelated Stress. J. Phys. Ther. Sci. 30: 1187-1192: Mahidol University, Thailand.

Bhavanani, AB, Ramanathan, M., Balaji, R., \& Pushpa, D. (2014). Comparative immediate effect of different yoga asanas on heart rate and blood pressure in healthy young volunteers. International Journal of Yoga. 2014: 7, 89-95.

Black, JM, Hawks, JH (2014). Medical Surgical Nursing Clinical Management for the expected results, Edisi 8. Singapore: Elsevier.

Chimkode, S. M., Kumaran, S. D., Kanhere, V. V., \& Shivanna, R. (2015). Effect of yoga on blood glucose levels in patients with type 2 diabetes mellitus. Journal of clinical and diagnostic research: JCDR, 9(4), CC01.

Cohen, D. L., Bloedon, L. T., Rothman, R. L., Farrar, J. T., Galantino, M. L., Volger, S., ... \& Townsend, R. R. (2011). lyengar yoga versus enhanced usual care on blood pressure in patients with prehypertension to stage I hypertension: a randomized controlled trial. Evidence-Based Complementary and Alternative Medicine, 2011.

Ministry of Health, Republic of Indonesia. (2014). Measurement and Inspection Guidelines. Jakarta $\mathrm{MOH}: \mathrm{RI}$.

Diguilo, M. \& Donna, J. (2014). Medical Surgical Nursing, Yogyakarta: Rapha Publishing.

Fawcett, J. (2010). Contemporary Nursing Knowledge: Analysis and Evaluation of Nursing Models and Theories, Second Edition. Philadelphia: FA Davis Company.

Gunawan-Lany, (2008). Hipertention. Penerbit Kanisius. Yogyakarta.

Hagins, M., Rebecca, S., Terry, S., \& Kim, I., (2015). Effectiveness of Yoga Hypertension: Systematic Review and Meta-Analysis. Hindiawi Publishing Corporation. Volume 2013 Article ID 649836, 13 pages http://dx.doi.org/10.1155/2013/649836.

Hajir., R. (2010). Easy Yoga - Healthy and Fit with Practical Yoga. Jakarta: Penerbit Bukune.

Health Office (2015). physical activity consumption of salty foods and incidence of hypertension in coastal communities. Retrieved from https://www.neliti.com/publications/325955/aktivitasfisik-konsumsi-makanan-asin-dan-kejadianhipertensi-masyarakat-pesisir.

Hendarti E., S., Hidayah, A., (2018) Giving Yoga Gymnastics Therapy Against Changes in Blood Pressure in the Elderly with Hypertension in Sidoarjo Regency. Prosiding Seminar Nasional Unimus Volume 1, 2018. e-ISSN: 2654-3257., p-ISSN: 26543168.
Ramos-Jiménez, A., Hernández-Torres, R. P., \& WallMedrano, A. (2011). Hatha yoga program determinants on cardiovascular health in physically active adult women. J Yoga Phys Ther, 1(103). DOI: 10.4172 / 2157-7595.1000103.

Kaplan, N.M, (2009). Kaplan's Clinical Hypertension. Philadelphia: Lipincott Williams \& Wilkins.

Ministry Health Republic of Indonesia. (2013). Basic Health Research Report. Jakarta: Pusat Data dan Informasi.

McCaffrey, R., Ruknui, P., Hatthakit, U. \& Kasetsomboon, P. (2005). The Effects of Yoga On Hypertensive Persons In Thailand. Holistic Nursing Practice, vol.19, no. 4, pp. 173-180.

Nopitasari, D., Sri Ratna Rahayu, (2017). Analysis of The Effect of Hatha Yoga on The Quality of Sleep and Immune System Among The Students in Public Health Postgraduate Program At UNNES. Public Health Perspective Journal 3 (1) (2018) 1 - 6. Semarang State University, Indonesia.

Okonta, NR, (2012). Does Yoga Therapy Reduce Blood Pressure in Patients With Hypertension?: An integrative review. Holist Nurs Pract; 26: 137-141. DOI: 10.1097 / HNP.0b013e31824ef647. PubMed: 22517349.

Palmer, A., \& Williams, B. (2009). Simple Guides for High Blood Pressure. Jakarta: Erlangga.

Polit, DF, \& Beck, CT (2012). Nursing Research: Generating and Assessing Evidence of Nursing Practice. 9th Edition. Philadelphia: Lippincot Williams \& Wilkins.

Riskesdas. (2013). Badan Penelitian dan Pengembangan Kesehatan Kementrian Kesehatan RI. Diperoleh tanggal 10 Januari 2018 dari http: www. riskesdas. Litbang depkes.go.id/download/laporan riskesdas.

Roche, L. T., \& Hesse, B. M. (2014). Application of an integrative yoga therapy programme in cases of essential arterial hypertension in public healthcare. Complementary Therapies in Clinical Practice, 20(4), 285-290. DOI: 10.1016 / j.cctp. 2014. 17443881. Madrid.

Satyanand, V., Bhakthavasala, R., Lilly, N., Shaik, M., Shaik, A. B., \& Aditya, M. (2014). Studying the role of yogic Pranayama in the management of Blood pressure. Int $J$ of Biomedical And Advance Research, 5(12), 609-11.

Smeltzer, SC, Bare, BG, Hinkle, JL, \& Cheever, KH (2013). Brunner \& Suddarth's Textbook of Medical-Surgical Nursing (12th ed.). Philadelphia: Lippincott Williams \& Wilkins.

Snyder, M. \& Lindquist, R. (2009). Complementary / Alternative Therapies In Nursing. 4th ed. New York: Spirnge.

Therese, AM, \& Murail, R. (2016). Yoga: Effective Therapy To reduce Blood Pressure Among Hypertension Clients. International Journal of Development Research, vol 6 (05), 7761-7765. ISSN: 2230-9926.

Widyatuti, (2008). Complementary Therapies in Nursing. Indonesian Nursing Journal, 12 (1), 53-57.

World Health Organization. (2013). A Global Brief Of Hypertension: Silent Kliller, Global Public Health Crisis. Accessed March 2018. 
http://www.int/cardiovasculardiseases/publications/gl obalbriefhypertension/es/index.html,WHO

Yoga, R., P. (2013). Yoga Pocket Book. Jakarta: An Nuha Publishing
Yoga, T. (2009). Avoid hypertension, consume 1 teaspoon salt per day. Retrieved from http//: www.depkes.go.id. 